\title{
Roman Darowski
}

\section{Gorgoniusz Ageison SJ (1604-1665), profesor w Akademii Wileńskiej}

Prawo Kanoniczne : kwartalnik prawno-historyczny 22/3-4, 263-275

1979

Artykuł został zdigitalizowany i opracowany do udostępnienia w internecie przez Muzeum Historii Polski w ramach prac podejmowanych na rzecz zapewnienia otwartego, powszechnego i trwałego dostępu do polskiego dorobku naukowego i kulturalnego. Artykuł jest umieszczony w kolekcji cyfrowej bazhum.muzhp.pl, gromadzącej zawartość polskich czasopism humanistycznych i społecznych.

Tekst jest udostępniony do wykorzystania w ramach dozwolonego użytku. 


\title{
MATERIAEY DO HISTORII NAUKI I LITERATURY PRAWA KANONICZNEGO W POLSCE
}

\author{
Prawo Kanoniczne
}

22 (1979) $\mathrm{nr} 3-4$

\section{ROMAN DAROWSKI SJ}

\section{GORGONIUSZ AGEISON SJ (1604-1665), PROFESOR W AKADEMII WILENSKIEJ}

Treść: Wstęp. - 1. Biografia. - 2. Spuścizna filozoficzna. 3. Spuścizna z zakresu prawa kanonicznego.

\section{Wstęp}

Gorgoniusz Ageison, Duńczyk, był jednym z wybitniejszych profesorów filozofii, teologii i prawa kanonicznego w Akademii Wileńskiej w XVII wieku. Jego działalność jednak nie została dotąd zbadana. O jego spuściźnie filozoficznej nie wspominają istniejące bibliografie, a jego spuścizna $z$ zakresu prawa kanonicznego, choć ubocznie (pod nazwiskiem defendensa) zasygnalizowana przez Estreichera, nie została dotychczas opracowana. A. Petrani szkicując dzieje nauczania prawa kanonicznego $w$ Akademii Wileńskiej nie wymienia Ageisona, stwierdza jedynie, że „o innych wykładowcach nic nie wiemy" ${ }^{1}$. Nieliczne drobne publikacje o Ageisonie posiadają charakter encyklopedyczny: zawierają jeđynie najważniejsze dane biograficzne, niekiedy riedokładne, a nawet błędne ${ }^{2}$.

Niniejszy syntetyczny artykuł zawiera źródłową biografię Ageiso-

1 A. Petrani, Historia prawa kanonicznego (wiek XVI-XVIII), (w:) Drieje teologii katolickej $w$ Polsce. Pod red. M. Rechowicza, t. 2, cz. 1, Lublin 1975, s. 509.

2 Polski stownik biograficzny, t. 1, Kraków 1935, s. 30 (S. Bednarski); T. Oracki, Stownik biograficzny Warmii, Mazur i Powiśla od potowy XV w. do 1945 roku, Warszawa 1963, s. 2; Encyklopedia katolicka, t. 1, Lublin 1973, s. 172 (K. Drzymała); R. Ple čk a i t is, Feodalizmo laikotarpio filosofija Lietuvoje, Vilnius 1975, s. 393, 406; Stownik teologów polskich. Praca zbiorowa pod red. E. H. Wyczawskiego (L. Grzebień; w druku). $z$ dawniejszych publikacji informacje o Ageisonie zawierają: G. A. Patrign an i, Menologio di pie memorie d'alcuni reIigiosi della Compagnia di Gesù... constinuate per G. Boero, vol. 1, Roma 1859, s. 171-172; J. Bend er, Geschichte der philosophischen und theologischen Studien in Ermland, Braunsberg 1868, s. 65, 70, 71; E. de $\mathbf{G}$ uilhermy, Ménologe de la Compagnie de Jésus, Assistance de Germanie, seconde série ,première partie, Paris 1899 , s. 35-36; S. Z a łęs ki, Jezuici $w$ Polsce, t. 2, Lwów 1901 s. 642, 643 (pomyłkowo jako Jerzy A.), t. 4, Lwów 1905, s. 96 . Zob. także pozycje przytoczone w następnych przypisach. 
na, przegląd jego spuścizny filozoficznej i prawniczej oraz omówienie zawartych w niej poglądów wraz z krótką ich charakterystyką.

\section{Biografia}

Gorgoniusz Ageison (Ageyson, Ageisson, Aagesen) urodził sie w r. 1604 w Kopenhadze ${ }^{3}$. Był synem Jana, który przebywał przeszlo rok (1587/88) w Seminarium Papieskim w Braniewie, ale z racji zdrowotnych został zwolniony. Ukończył później studia filozoficzne W Ołomuńcu i na przelomie XVI i XVII w. był rektorem szkoły w Kopenhadze, gdzie był czynnym działaczem katolickim, $m$. in. posyłając młodzieńców na studia do Braniewa. W r. 1605 został skazany na wygnanie i osiadł $w$ Reszlu, gdzie zmarł ${ }^{4}$. Gorgoniusz uczył się od sierpnia 1618 r. w Seminarium Papieskim w Braniewie, a po ukończeniu retoryki wstapil dnia 17 VII 1622 r. do litewskiej prowincji i'owarzystwa Jezusowego i odbył dwuletni nowicjat w Wilnies. W latach 1625-1628 studiowal filozofię $w$ Akademii Wileńskiej pod kierunkiem Tomasza Rostogi (logika i filozofia przyrodyb), Pawła GołŁbecjusza (matematyka) i Andrzeja Klingera (metafizyka i prawdopudobnie także etyka). Przez następne trzy lata uczył w niższych klasach w Płocku, a w latach 1631-1635 odbył studia teologiczne w A.kademii Wileńskiej. Po trzecim roku studiów przyjął w Wilnie święcenia kapłańskie. W r. 1636/37 odbyl w Nieświeżu tzw. trzecią probację, czyli studium prawa zakonnego i duchowości ignacjańskiej. W r. 1638/39 uczył w Pultusku teologii moralnej (casus) i przygotowy-

3 "Gorgonius Ageison, Danus Kopenhagensis annorum 14, venit anno: 1618 in aug. Studet in syntaxi...", G. L ü $\mathrm{hr}$, Die Martrikel des päpstlichen Seminars zu Braunsberg 1578-1798, Königsberg 1925, s. 73, nr 489 .

${ }_{4}$ Tamże, s. 41-42, nr 164; R. Wehner (Jesuiten im Norden, Paderborn 1974, s. 41 i 132), powołując się na prace Ett årtusende katolskt liv i Malmö och Skåne, Lund 1972, podaje, że Jân Aẹeison byl rektorom szkoły nie w Kopenhadze, lecz w Malmö i że tam urodził sie Gorgoniusz. Zob. także V. H el k, Laurentius Nicolai Norvegus S. J., København 1966 , s. 400. Nie jest wykluczone, że jako miejsce swego urodzenia Gorgoniusz podał w Braniewie zamiast mniej znanego Malmö bardziej znana, a niezbyt odległa Kopenhage.

5 Przy ustalaniu biegu życia i prac Ageisona opierałem się przede wszystkim na zachowanych w Centralnym Archiwum Jezuitów w Rzymie (Archivum Romanum Societatis Iesu; skrót: ARSI) katalogach rocznych z lat 1625-1666, dzialy: Lith. 6, Lith. 56, Germ. 132 oraz na katalogach trzyletnich. Lith. 6-13. Fotokopie lub mikrofilmy tych źródel znajdują się w Archiwum Towarzystwa Jezusowego w Krakowie. Zob. nadto koncepty listów generałów zakonu do Ageisona jako doradcy (consultor) przełożonego: W. Carrafy do Braniewa 17 III $1646 \mathrm{r}$. (ARSI, Germ. 110, s. 337) i G. Nickela do Wilna w r. 1655, 1663 i 1664 (tamże, s. 745, 1082, 1084).

6 Rękopiśmienne wykłady (dyktaty) Rostogi z filozofii przyrody (fizyki) $z$ tego czasu zachowaly się $w$ Bibliotece Uniwersyteckiej $w$ Wil. nie, F 3 - 2091; por. R. Plečkait is, dz. cyt., s. 469, 505 . 
wał się do wykładów filozofii. Dnia 8 I 1640 r. złożył w Wilnie uroczysta profesję czterech ślubów ${ }^{7}$. W latach 1640-1643 wykładał filozofię w Akademii Wileńskiej, prowadząc kolejno kurs logiki, filozofii przyrody (fizyki) i metafizyki. $Z$ tego okresu jego pracy dydaktycznej pochodzi omówiony poniżej zbiór tez z zakresu filozofii przyrody. W r. 1641 uzyskał równoważne wówczas z doktoratem magisterium sztuk wyzwolonych i filozofii ${ }^{8}$. Podczas ostatniego roku prowadzonego przez Ageisona kursu (1642/43) filozofię moralną, czyli etykę wykładał Jan Chądzyński. Od r. 1643 Ageison wykładał teologie w Braniewie. W $1645 \mathrm{r}$. uzyskal promocję doktorską z teologii; promotorem był Benedykt de Soxo, rektor Akademii Wileńskiej 9. Prawdopodobnie w r. 1647 Agieison rozpoczął wykłady teologii w Akademii Wileńskiej, które prowadzil do r. 1651 z przerwą w r. 1649/50, kiedy to był kaznoázieja niemieckim w Warszawie ${ }^{10}$. W latach 1651--1655 wykładał pra-wo kanoniczne $w$ Akademii Wileńskiej. Trwałym owocem jego pracy W tym okresie jest zbiór materiałów na dysputę. Ageison był również przez kilka lat wicekanclerzem Akademii i prefektem studiów.

Od 2 VI 1658 do 6 XII 1661 r. Ageison był najpierw wicerektorem, a po roku rektorem kolegium braniewskiego $i$ organizował studia po zniszczeniach spowodowanych wojną ze Szwecją ${ }^{11}$. Prowadził także

7 Informationes (przed profesją), ARSI, Germ. 112, f. 176; Professi, Germ. 11, f. 116, 100, 103 (wlasnoręcznie napisana formula ślubówr).

${ }_{8}$ "Anno Domini 1641 a R. P. Fabricio Bamfi Visitatore Societatis Iesu Provinciarum Regni Pol. et M. D. L. Eukiszkis sunt promoti: P. Gorgonius Ageison Ph. atq, LL. Art. M[agister]", Laureae academicae... in Alma Academia Vilnensi Soc. Iesu, rkp. z Biblioteki Czartoryskich w Krakowie, sygn.: Kurat. Wil. nr 3 (obecnie w depozycie Biblioteki Uniwersyteckiej w Wilnie, sygn. F 2 DC $\mathrm{Nr}$ 1), s. [318]. O uzyskaniu przez Ageisona doktoratu sztuk wyzwolonych i filozofii świadczy S. Rostowski, Lituanicarum Societatis Jesu historiarum libri decem, recognoscente Joanne Martinov, Parisiis-Bruxellis 1877, s. 434.

9 Zob. Laureae academicae, rkp. cyt., s. [98]; S. Rostowski, dz. cyt., s. 433 .

10 Na dokładne ustalenie kolei życia Ageisona w tym okresie nie pozwalają dostępne źródła. Katalogi roczne wskazują na to, że w latach 1643--1649 byl profesorem teologii $w$ Braniewie. Tymczasem $z$ katalogów trzyletnich wynika, że w r. $1648 / 49$ i w r. 1650/51 przebywał w Wilnie. Por. Cat. primus et secundus Coll. Viln. Anno 1649, ARSI. Lith. 9, f. $203^{\mathrm{v}}$ oraz analogiczny katalog z r. 1651, tamże, Lith. 9, f. $238^{\mathrm{v}}$.

11 Hist. Coll. Brunsb., 1655-1660, ARSI, Lith. 40, f. 194-194v. Katz:log tzw. trzyletni Kolegium Braniewskiego z r. 1660 podaje syntetyczny wykaz studiów i zajęć Ageisona od wstąpienia do zakonu aż do r. 1660 oraz krótką sylwetkę charakterologiczną. Ageison był wówczas rektorem w. Braniewie i do jego obowiązków należało zebranie danych i przekazanie ich kurii prowincjalnej. Nożna więc przypuszczać, że dane te są dokładne. „P. Gorgonius Ageison Danus. Annorum 56. Valetudinis mediocris. Societatem ingressus 17 Iulii 1622. Studuit extra Societatem ad Rhetoricam inclusive. In Societate Rhetoricae anno uno. Philosophiae 3. Theologiae 4. Docuit Poësim annis 3. Rhetoricam 2. Philosophiam 3. Theologiam moralem 1. Positivam 2. 
prace duszpasterską wśród protestantów. W ostatnich trzech latach swego życia pelnił różne, mniej eksponowane obowiązki w Wilnie i Braniewie. Zmarł w Braniewie dnia 9 I 1665 roku ${ }^{12}$.

Współcześni i późniejsi uważali Ageisona za jednego z wybitniejszych profesorów. Niestety, nic nie wiadomo o istnieniu skryptów ídyktatów) z jego wykładów. Dlatego do odtworzenia jego poglądów filozoficanych i prawnych mogą służyć wyłącznie przygotowane przez niego materialy na dysputy $z$ zakresu tych dyscyplin.

\section{Spuścizna filozoficzna}

Istniejące bibliografie nie rejestrują żađnej spuścizny Ageisona z zakresu filozofii. Należy przeto wyjaśnić, jak doszło do jej ustalenia. Stalo się to możliwe dzięki pracom mającym na celu przygotowanie możliwie pelnej bibliografii filozoficznej jezuitów w Polsce.w XVII wieku, w tym także druków szkolnych, czyli takich, które były związane $z$ nauczaniem filozofii. Te ostatnie $w$ bibliografiach figuruja zwyk.le pod nazwiskiem defendensa, czyli studenta, który podczas publicznej dysputy bronil określonych tez. Nierzadko nazwisko autora, czyli kierownika dysputy nie jest w ogóle wymienione. W takich przypadkach starano się ustalić autorstwo druku przy pomocy materiałów żródlowych, przede wszystkim z Rzymskiego Archiwum Jezuitów. $\mathrm{Na}$ podstawie zachowanych tam $w$ większości katalogów rocznych, a niekiedy $z$ pomocą katalogów trzyletnich moźna stwierdzić, kto $w$ danym roku uczył filozofii $\mathrm{w}$ określonym kolegium.

Ustalenie autorstwa Ageisona w przypadku dziełka pt. Mundus philosophicus było jednym $\mathrm{z}$ wyników wspomnianej powyżej pracy. Bibliografia polska Estreicherów notuje pozycję Mundus philosophicus, która stanowila zbiór tez na dysputę przeprowadzoną $w$ Akademii wileńskiej $\mathrm{W}$ celu uzyskania stopnia magistra, pod nazwiskiem studenta tejże Akademii i defendensa tez, alumna Seminarium Papieskiego, Czecha Andrzeja Waclawa Borzeckiego. Druk ten zresztą znajduje się co najmniej w dwóch bibliotekach. $z$ praktyki szkolnej jezuitów, a także z praktyki innych szkół - co zresztą jest zupełnie zrozumiałe - wiadomo, że autorem tez i ewentualnie innych materiałów na dysputę nie był defendens, lecz profesor wykładający filozofię $w$ danym roku, który też z reguły był przewodniczącym dysputy (praeses).

Ius Canonicum 4. Theologiam 3. tiae lectionis 1. Theologiam Scholasticam 8. Fuit Praefectus Scholarum Inferiorum anno 1. Superiorum 4. Regens Alumnatus Pontificii 1. Concionator 4. Vicerector 1. Rector 1. Est Sacrae Theologiae Doctor. Professus 4 votorum factus 8 Ianuarii 1640. [inną ręką:] Ingenii, iudicii, prudentiae et experientiae bonae. Complexionis temperatae. Valet ad docendum in quavis Schola, ad concionandum, ad conversandum cum proximis". ARSI, Lith. 12, f. 5 .

12 ARSI, Hist. Soc., 48, f. 56 (Defuncti); Defuncti in Coll. Brunsb. $\mathrm{S}$ J. ab a. 1661-1665 inclusive, Lith. 61, f. 286-287 (nekrolog). Zob. także J. Poszakowski, De viris illustribus Prov. Lithuaniae, Archiwum T. J. w Krakowie, rkp. 1536, s. 3. 
$\mathrm{Z}$ ustaleń dokonanych $\mathrm{w}$ biografii Ageisona wiadomo, że wykładał on filozofię $w$ Akademii Wileńskiej $w$ latach 1640-1643, prowadząc cały trzyletni kurs począwszy od logiki, poprzez filozofię przyrody (fizykę), a skończywszy na metafizyce. Nie wykładał jednak matematyki i filozofii moralnej (etyki), gdyź do tych dyscyplin byli osobni wykładowcy. Omawiany zbiór tez dotyczy szeroko rozumianej filozofii przyrody, stąd mogłaby powstać wątpliwość, czy jego autorem jest Ageison, który w r. 1642/43 wykładał nie filozofię przyrody, lecz metafizykę. Jednakże - jak wynika $z$ danych na karcie tytułowej była to dysputa $w$ celu uzyskania magisterium filozofii, to zaś można było uzyskać najwcześniej na zakończenie trzyletniego studium filozoficznego. O ukonczeniu trzech lat filozofii pisze sam Borzecki w dedykacji-zbioru ${ }^{13}$. Na karcie tytulowej zaś istnieje informacja, że jest on słuchaczem metafizyki i etyki, które wykładano na trzecim roku. Kandydat do magisterium kończyl więc rok trzeci, podczas którego metafizykę wykładał Ageison, a etykę Jan Chądzyński. Tezy na dysputę na koniec kursu i do uzyskania stopni naukowych układał ten, kto prowadził cały trzyletni kurs (logikę, filozofię przyrody i metafizykę). Matematyka (na drugim roku stuđiów) i etyka (na trzecim roku) byly uważane za dyscypliny $w$ pewnym sensie poboczne, stąd $i$ wymagania stawiane wykładowcom tych przedmiotów były niższe. $\mathrm{Ci}$ z reEuły nie przewodniczyli dysputom. Dlatego też Ageisona trzeba uznać za autora zbioru Mundus philosophicus.

Zwrócimy obecnie uwagę na szczegóły bibliograficzne oraz na zawartość zbioru.

Mundus philosophicus ... Abrahamo Woyna ... Episcopo Vilnensi, Cancellario Almae Academiae Vilnensis S. I. ... dedicatus et defensus $a b$ Andrea Venceslao Borzecki, Bohemo, Summi Pontificis alumno, laureae magisterii philosophici candidato et in eadem Academia me-taphysices et ethices auditore. Anno 1643.

Vilnae, Typis Academicis Societatis Iesu [1643] 4º 12 kart nieliczbowanych ${ }^{14}$.

Zbiór składa się z 7 głównych części i zawiera łącznie 54 tezy, na ngół dość obszerne. Oto poszczególne części wraz z danymi o ich obEetości i ilości tez.

k. 2-2v: dedykacja bpowi Wojnie podpisana przez Borzeckiego

k. 3-4v: De corpore ... (tezy I-VIII)

15. $4^{\mathrm{v}}-5^{\mathrm{v}}$ : De coelo et coelestibus (IX-XIII)

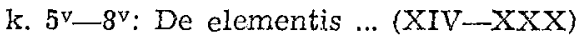

k. 8v-10: De viventibus et sentientibus (XXXI-XXXIX)

13 „Mundum philosophicum, quem in Alma Academia Vilnensi seduIus triennio perlustravi...", k. 2, początek.

${ }^{14}$ Es treicher, t. XXI, Dopełnienia i sprostowania, s. II (pod. Borzecki Andreas Venceslaus). Egzemplarze druku znajduja sie w Bibliotece Narodowej $w$ Warszawie, sygn.: XVII. 3. 1558 oraz $w$ Bibliotece Uniwersyteckiej $\mathrm{w}$ Wilnie, sygn.: III - 11519. 
k. $10-10^{\mathrm{v}}$ : De homine (XL-XLIII)

k. $10^{\mathrm{v}}-11^{\mathrm{v}}$ : De Deo (XLIV-XLIX)

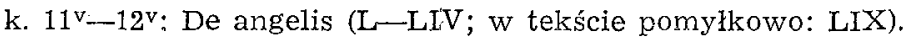

Zbiór tez pt. Mundus philosophicus (Swiat w ujęciu filozofii) należyr do ówczesnej filozofii przyrody (fizyki), zawiera jednak zagadnienia: należące współcześnie do kilku dyscyplin: do filozofii przyrody, psychologii, antropologii filozoficznej, teologii naturalnej, a nadto do astronomii, fizyki $i$ chemii (o żywiołach) oraz do teologii (o aniolach).

Właściwa część filozofii, przyrody, czyli fizylka jest wedlug Ageisona prawdziwą nauką i to nauką spekulatywną, której adekwatnym przedmiotem jest ciało substancjalne rozważane całościowo (corpus substantiale completum, teza I). Przy powstawaniu (in fieri) posiada ono trzy zasady: materię, brak formy (privatio), oraz samą formę, zasady zaś ciała już ukonstytuowanego stanowią materia i forma. Materia pierwsza jest czystą możnością bierną, posiada jednak częściowa samoistność, własne istnienie oraz nie określoną jeszcze bliżej wielkośćc ${ }^{15}$. Formy materialne posiadają własną samoistność częściową ${ }^{16}$. Przyczy na jest tym, co per se wplywa na wytworzenie istoty ${ }^{17}$. Ageison wyróżnia za Arystotelesem cztery rodzaje przyczyn: materialna, formalną, sprawczą i celową. Działanie celowe charakteryzuje przede wszystkim byty wolne, ale celowo, choć w sposób niedoskonały, działają także zwierzęta. Szczęśliwy zbieg okoliczności (fortuna) i przypadek stanowią przyczyny przypadłościowe, los (fatum) zaś to stała cecha tkwiąca w rzeczach zmiennych, zależna jednak od opatrzności bożej. Wielkość ciągła (continuum) składa się z najmniejszych cząstek naturalnych (atomów), fizycznie niepodzielnych, ale podzielnych matematycznie ${ }^{18}$. W zagadnieniach ruchu, czasu, miejsca itp. Ageison idzie zasadniczo za Arystotelesem, mimo że na niego się nie powołuje.

Zwraca uwage stosunkowo obszerne potraktowanie zagadnienia ży wiołów (elementa, t. XIV-XXX: ogień, powietrze, woda i ziemia). W rozwiązaniach znać wyraźne wpływy poglądów Arystotelesa oraz cwczesnego stanu nauk przyrodniczych.

W psychologii Ageison za Stagirytą definiuje duszę jako akt pierw.szy ciała organicznego, fizycznego, posiadającego życie w możności. Tusza stanowi formę istoty żyjącej i dzieli się na wegetatywną, sensytywną i rozumną. Ożywia także krew, włosy, paznokcie, zęby itd. Dusza wegetatywna posiada trzy wladze, odrębne od duszy i między

15 ,[Materia] pura est potentia passiva, habet tamen actum entitativum... Ut partiali subsistentia et propria existentia, ita et quantitate secundum interminatas rationes coaeva sibi gaudet"; t. II.

${ }_{10}$,[Formae materiales] propriam habent subsistentiam partialem:, t. III.

${ }_{17}$ "Causa est quae per se influit producendo essentiam", t. IV.

${ }_{18}$ "...Continuum componitur ex minimis naturalibus physice et intrinsece indivisibilibus, mathematic et extrinsece divisibilibus", t. VI. 
sobą, tj. przyjmowania pokarmu, wzrostu i rozmnażania. Dusza rozumna jest cała $w$ całym ciele i cała w poszczególnej jego części. Istota żyjąca posiada jedną tylko formę całościową; nie ma w niej form częściowych, np. cielesności itp. Zmysły zewnętrzne, których jest pięc, różnią się między sobą dzięzi właściwym sobie przedmiotom, ku którym się kierują. Zmysł wewnętrzny jest tylko jeden i posiada siedzibę w mózgu, ale w przypadku zwierząt, które po podziale (przecięciu) zachowują życie, jest on rozsiany po calym ciele.

Osobna część twierdzeń poświęcono człowiekowi (De homine). Człowiek został ustanowiony przez Boga królem wszystkich bytów żyjących. Posiada duszę ze swej natury duchową, prostą, czyli nie zlożoną, która stanowi prawdziwie (vere) formę człowieka i formalnie zawiera duszę wegetatywną i sensytywną. Dusza ludzka zostaje stworzona bezpośrednio przez Boga wówczas, gdy ciało zdolne jest do wykonywania funkcji życiowych. Duszę rozumną $w$ czlowieku nie poprzedza żađna inna dusza. Tylko człowiek posiada intelekt i wolę. Chcenie następuje po poznaniu, które dokonuje się z pomocą wyobrażenia przedmiotu (phantasma) przy udziale umysłu czynnego, przyjmującego podobiznę poznawcza przedmiotu i przekazującego ją umysłowi biernemu. Te dwie funkcje umysłu nie różnią się między sobą rzeczowo. Kresem poznania intelektualnego jest „slowo myślne" (verbum mentis), umyslowy obraz przedmiotu, czyli pojęcie. Proste spostrzeżenie, sąd i rozumowanie stanowią główne akty ludzkiego intelektu. W umyśle ludzkim może istnieć równocześnie ścisła wiedza o jakimś przedmiocie oraz opinia o nim.

W omawianym zbiorze tez znalazły się również niektóre twierdzenia dotyczące teologii naturalnej. Bóg jest bytem absolutnym (ens a se), całkowicie niezłożonym (prostym), ze swej istoty nieskończonym i jedynym. Człowiek może poznać jego istnienie w sposób oczywisty. Swiat został stworzony przez Boga (w ciąu 6 dni!) w czasie. Swiadczy o tym rozum i tak też uważal Arystoteles. Możliwe by było także odwieczne stworzenie świata, ale jako bytu trwałego (ens permariens), a nie jako bytu zmieniającego się stopniowo. Bóg współdziała $z$ przyczynami stworzonymi w czynieniu dobra, a nie zła. Współdziałanie to jest identyczne $z$ działaniem stworzeń. Wzięte $w$ odniesieniu do Boga, nazywa się współdziałaniem przyczyny pierwszej, wzięte zaś w odniesieniu do czlowieka - współdziałaniem przyczyny stworzonej ${ }^{19}$. Bóg również utrzymuje $w$ istnieniu skutki dzialania przyczyn stworzonych (conservatio).

W zakresie astronomii w części De coelo et coelestibus Ageison przedstawia poglądy pod wieloma względami przebrzmiałe. Charakterystyczną jest rzeczą, że nic nie mówi o systemach slonecznych. Nie

19 „Concursus autem hic est ipsa actio creaturae, quae relata ad causam independentem, concursus causae primae, relata vero ad causam dependentem, concursus secundae causae merito dicitur", t. XLVI. 
brak mu jednak pewnego zmysłu krytycznego, np. w zagadnieniu: wpływu gwiazd na człowieka oraz $w$ stosunku do przepowiedni astrologów (t. XII), z drugiej jednak strony $w$ zbiorze znajduje się wiele: zasłyszanych dziwnych zdarzeń, co ów zmysł krytyczny podaje w wątpliwość.

Podsumowując ten krótki wykład ważniejszych poglądów Ageisona zauważmy najpierw, że brak w nich omówienia logiki i metafizyki. Zreferowane poglądy dotyczą tylko części filozofii, mianowicie filozofi: przyrody, rozumianej jednak bardzo szeroko, wskutek czego znalazły się $\mathrm{w}$ niej zagadnienia, które $\mathrm{z}$ czasem zostały wyeliminowane $\mathrm{z}$ zakresu fillozofii i stały się przedmiotem powstających wtedy nauk przyrodniczych. Nie miały one jeszcze wówczas ustalonego miejsca. Szkoła. srednia byla ze swej istoty humanistyczna, a w zakresie szkoly wyższej nie bylo dla nich osobnego kierunku. Z trzech najbardziej wówczas obieranych kierunków: filozofii, teologii i prawa, filozofia byla mimo wszystko najbardziej zblizona do zagadnień przyrodniczych zwłaszcza znaczna jej częśc: filozofia przyrody (fizyka). Nic więc: dziwnego, ze zagadnienia te lączono właśnie $z$ filozofią. Nie była to: sytuacja korzystna ani dla filozofii, ani dla nauk przyrodniczych. Dlatego w miarę jak nauki przyrodnicze zyskiwały samodzielność, odłączały się od filozofii i stopniowo dalej się różnicowaly i dzieliły.

Gdy chodzi o typ tej filozofii, to jest ona w znacznej mierze eklektyczna. Przeważają oczywiście wpływy Arystotelesa, zmodyfikowane $\mathrm{w}$ niektórych zagadnieniach (np. stworzenie świata $\mathrm{w}$ czasie) przez Tomasza $z$ Akwinu. Duży wpływ na filozofię Ageisona wywarł Suárez. (poglądy na materię i formę, definicja przyczyny, nieprzyjęcie różnicy rzeczowej między rozumem czynnym i biernym). Wreszcie $w$ zagadnieniu natury ciał Ageison okazuje się atomistą, co budzi zdziwienie, gdyż - jak wynika z dotychczasowych wycinkowych badań byl to pogląd rzadko reprezentowany przez jezuitów $w$ Polsce.

W sumie filozofia ta nie odbiega od ówczesnego poziomu europejskiego. I w niej także widać próby poszukiwań, charakterystyczne dla filozofii XVII wieku.

\section{Spuścizna z zakresu prawa kanonicznego}

Do poznania poglądów prawniczych Ageisona dysponujemy jednym dziełkiem, stanowiącym materiał na publiczna dysputę, jaka w 1652 r. pod jego kierunkiem odbył w Akademii Wileńskiej jego uczeń Mateusz Jan Szenrath. Nie do przyjęcia jest opinia, że autorem dzielka jest defendens, czyli ten, kto bronił zawartych w nim konkluzji, a więc Szenrath. W tym względzie uwagi podane poprzednio przy omawianiu autorstwa spuścizny filozoficznej Ageisona i tutaj w pewnej mierze mają zastosowanie. Sprawa jednak jest o tyle prostsza, że nazwisko Ageisona jako przewodniczącego dysputy widnieje na karcie tytuło- 
wej. W świetle tej informacji autorstwo Ageisona nie może budzić wątpliwości.

Oto tytul $i$ inne dane bibliograficzne omawianej pracy:

Conclusiones canonicae de constitutionibus ecclesiasticis et praelatorum ecclesiasticorum legislatrice potestate ex lib. I Decretalium, Tit. 2, quas sub felicissimis auspiciis ... Praelatorum et Canonicorum Perillustris Capituli Varmiensis, Praesidente Admodum Reverendo Patre Gorgonio Ageison Societatis Iesu, Sacrae Theologiae Doctore et in Alma Universitate Vilnensi Soc. Iesu SS. Canonum Ordinario Professore, ad disputandum proposuit et defendendas suscepit in eadem Academia Vilnensi Matthaeus Ioannes Szenrath Pruthenus, Artium LL et Philosophiae Magister et I uris] Vitriusque] Auditor.

[Vilnae] Typis Academicis Societatis Iesu. Anno M.DC.LII [1652], format folio, 17 kart nieliczbowanych 20.

Publikacja zawiera tezy (conclusiones) prawnicze z zakresu drugiego tytułu (titulus). I księgi Dekretałów papieża Grzegorza IX, które stanowily obowiązujące wówczas prawo kościelne. Tytul 2 dotyczy ustaw kościelnych oraz organów włađzy prawodawczej Kościoła.

$\mathrm{Na}$ początku zbioru $\left(k, 2-2^{v}\right)$ znajduje się dedykacja prałatom i kanonikom Kapituły Warmińskiej podpisana przez Szenratha, który po trzyletnich studiach filozoficznych uwienczonych stopniem magistra filozofii i nauk wyzwolonych i czteroletnich studiach teologicznych podjąl studia na Wydziale Obojga Praw w Akademii Wileńskiej ${ }^{21}$.

Rozprawa składa się z 73 konkluzji oraz 71 krótkich aksjomatów prawnych. Konkluzje podzielone są na 7 rozdziałów, które traktują kolejno o naturze $\mathrm{i}$ istocie ustaw kościelnych, o władzy prawodawczej Kościola (najobszerniej potraktowany, k. 5-8v, concl. IX-XXX), o podmiocie ustaw kościelnych, o skutkach ustaw, czyli o obowiązku ich zachowania, o różnych rodzajach ich interpretacji oraz o niewiedzy (ignorantia) w kwestii prawa. Ostatnie dwa rodziały luźno tylko wiążą się z Dekretałami i stanowią bardziej oryginalny wkład autora. W $\mathrm{r}$. VI zostały przedstawione propozycje poprawek do prawa cywilnego, a $\mathrm{W}$ r. VII podano wykaz zwyczajów wykraczających poza ogólne prawo kościelne.

Ponieważ $r$. I-V opierają się $w$ zasadzie na Dekretałach, odtwarzając zawarte tam ustawy, dlatego zasygnalizuję $z$ nich tylko wybrane, bardziej interesujące zagadnienia. Obszerniej natomiast omówię roz-

20 Estreicher, t. XII, s. 70 (pod: Ageisson Georgius (!) odsyłacz do Szenratha); t. XXX, s. 271 (pod: Szenrath Mateusz Jan), gdzie została podkreślona wartość dziełka. Egzemplarze tego druku znajduja sie w Bibliotece Ossolineum we Wrocławiu, sygn.: XVII-15891-IV (Archiwum Towarzystwa Jezusowego $w$ Krakowie posiada mikrofilm tego egzemplarza) oraz w Bibliotece Uniwersytetu Warszawskiego, sygn.: 4 g. 8.7.9 (brak ostatniej karty).

${ }_{21}, \ldots$ post emensum triennio in Philosophia et quadriennio in Theologia studii cursum animum ad Iuris Vtrisque sacratissimas leges addiscendas adieci..." (k. $\left.2^{\mathrm{v}}\right)$. 
działy VI i VII, które wysuwając propozycje poprawek do prawa cywilnego posiadają większe znaczenie.

Podstawowa $w$ tej tematyce definicja prawa przejęta została od św. Tomasza z Akwinu. Prawo jest to ,właściwe prawidło postępowania, przez władzę publiczną ogloszone spoleczności wraz z wola zobowiązania jej na stałe" 22 .

Prawodawcza władza Kościoła różni się od świeckiej pochodzeniem, przedmiotem i celem, a władza świecka jest jej podporządkowana (subordinata). Jednakże władza papieża $w$ normalnych warunkach nie rozciąga się na sprawy innych państw, ani na sprawy swieckie. Władza i jurysdykcja papieza pochodzi z ustanowienia Chrystusa, a nie od kleru rzymskiego lub kardynałów, biorących udział w jego wyborzẹ.

Synody narodowe, prowincjoneine i diecezjalne, jeśli nie zawierają uchwal przeciwnych prawu powszecnnemu lub ogólnie przyjętym zwyczajom, ściśle biorąc nie wymagają aprobaty papieża. Do ważności jednok dokonanego wyboru biskupa nieodzowne jest potwierdzenie papieża. Biskup za zgoda kapituły i kleru może prosić o subsidium charitativum, nie powinien jednak domagać się go od biednych.

Dzieci, które nie doszły jeszcze do używania rozumu, i umysłowo chorzy (amentes) nie podlegają żadnym prawom. $Z$ chwila zaś dojścia do używania rozumu podlegaja tym prawom, których materia odpowiada ich wiekowi. Istnieje prawdopodobna opinia, że cenzur kościelr.ych nie zaciąga się przed dziesiątym rokiem życia. Przed siódmym rokiem życia dziecko, które świadomie popełnia zabójstwo, nie popada w nieregularność (irregularitas).

Epikia to ulgowa interpretacja prawa, wyjaśniająca, że jakiś przypadek ze względu na szczególne okoliczności nie zawiera się w prawie ogólnym. Mogą ją stosować także osoby prywatne wg następujących reguł: 1) jeżeli zachodzą dwa nakazy, których równocześnie nie można zachować, można pominąć mniej ważny; 2) jeśli zachowanie prawa przeszkadza większemu dobru; 3) jeśli zachowanie prawa jest zbyt trudne i na pewno wiadomo, ze prawodawca nie chciał stosować tak wielkiej surowości (concl. XLIX).

Gdy w jakiejś wątpliwej sprawie istnieją różne opinie doktorów, jedna pradopodobna, a druga bardziej pradopodobna (probabilior), wówczas tak sędziemu jak i osobie prywatnej wolno iść za zdaniem prawdopodobnym z pominięciem bardziej pradopodobnego (LVI). Ageison jest więc zwolennikiem probabilizmu.

W r. VI przedstawione zostały interesujace propozycje poprawek do prawa cywilnego na podstawie prawa kanonicznego. Większość tych poprawek dotyczy prawa polskiego.

Ageison domaga się zakazu zawierania małżeństw między dziećmi

${ }^{22}$ „Lex quasi lecta vivendi regula et norma, recte definitur a S. Thoma sic: Est recta agendorum ratio, a publica potestate communitati denunciata, cum voluntate eam perpetuo obligandi" (Conclusio II). 
braci, między dziećmi sióstr oraz między dzieckiem brata i dzieckiem siostry, na co pozwalało prawo cywilne. Prawo cywilne nie uznające małżeństwa między porywaczem a porwaną należy $w$ myśl Soboru Trydenckiego poprawić $w$ ten sposób, że małżeństwo to będzie nieważne, jak dlugo porwana znajduje się pod władzą porywacza. Jeśli jednak odzyskawszy wolność i bezpieczeństwo zechce go mieć za męża, wówczas małżeństwo będzie ważne. Zniesienia lub poprawienia wymagają prawa cywilne ustalające pewne kary dla tych, co po rozwiązaniu pierwszego małżeństwa chcą zawrzeć drugi związek; poprawienia wymagają też prawa zezwalające na list rozwodowy i rozwiązarie małżeństwa. Nie posiadają ważności prawa cywilne zabraniające związku między pewnymi rodzajami ludzi, np. przepisy, które karza kobiety zawierające związek małżeński z osobami obcymi (externi); niektórzy prawnicy wyrażają wątpliwości na temat siły wiążącej ustaw miejskich zakazujących małżeństwa z obcymi, nie podlegającymi jurysdykcji miejskiej, tym kobietom, którym z dochodów rocznych miasta przygotowano posag. Prawa cywilne wzbraniające kobietom małżénstwa bez zgody ojca lub braci są $w$ świetle prawa kanonicznego zakazane. Niektóxzy jednak, np. Soto, stwierdzają, że takie prawa w pewnych okolicznościach moga być sprawiedliwe. Podobnie sprawa wygląda w przypadku dziewcząt młodocianych oraz małżeństw zawartych bez wiedzy rodziców z człowiekiem o wiele niższego stanu i nierównej kondycji, mimo że takie małżeństwa będą ważne.

Małżonkowi lub ojcu nie wolno zabić żony lub córki przychwyconej na cudzołóstwie, a prawa cywilne, które na to pozwalają, są zniesione przez prawo kanoniczne. Dzieciom, także nieprawym, należą się alimenta od ojca, pobodnie jak w przypadku dzieci chorych fizycznie lub umysłowo na rodzicach spoczywa obowiązek ich utrzymania. $Z$ prawa naturalnego bowiem należy utrzymać i wychować zarówno dzieci prawe, jak i nieprawe.

Prawa cywilne nieslusznie pozwalają nieprawemu (malae fidei) posiadaczowi dóbr na korzystanie $z$ nich (ut usucapiat) i na nabycie prawa ich wlasności przez zasiedzenie (... et praescribat). Prawa zaś zezwalające na lichwe (usura) wymagaja poprawek. Podobnie w sprawie kupna-sprzedaży: zakazana jest, także w sumieniu, sprzedaż rzeczy ze sumę około połowy większą lub mniejszą od sprawiedliwej wyceny, a sprzedawca zobowiązany jest do restytucji lub kupujący do poủniesienia ceny do rzeczywistej wartości rzeczy.

Prawa cywilne wymagające do sporządzenia testamentu 7 lub 5 swiadków nie posiàdają ważności w tych sprawach, które dotyczą dziel pobożnych (ad pias causas), gdzie wystarczają 3 lub 2 świadkowie. Wg praw cywilnych przyrzeczenie (promissio) lub układ zwykły (pactum nudum) nie nakładają obowiązku ich zachowania, jednakże w sumieniu (in foro conscientiae) każdy jest zobowiązany wypełnić układ zwykły. Podobna sytuacja zachodzi w przypadku przyrzeczenia złożonego osobie nieobecnej. 
Wg praw cywilnych spadkobierca zobowiązany jest wyplacić należności ciążące na spadku, nawet gdyby sam spadek na to nie wystarczał. W sumieniu jednak nie jest on do tego zobowiązany.

Prawa cywilne nie tylko nie karzą, ale nawet nagradzają wróżbitów (magos) i czarowników (veneficos), którzy stosują czary przeciw deszczom, wiatrom i gradom. Czynności te $w$ myśl prawa kanonicznego są niedozwolone.

Wg praw świeckich wolno przekupić oskarżyciela w sprawie kryminalnej (in causa sanguinis accusatorem corrrumpere), tego jednak zabrania prawo kanoniczne.

W r. VII zostały wymienione zwyczaje, wykraczające poza ogólne prawo kościelne (Proponuntur quaedam, quae a Iure communi exorbitant). Zasygnalizuję niektóre z nich.

Korupcją (corruptela) nazywa autor wybór biskupa równocześnie przez ludzi świeckich i przez kanoników. Swieccy $z$ racji fundacji mają prawo mianowania, ale tylko księży. Godziwy jest także zwyczaj dokonywania wyboru (np. na proboszcza) przez księży i powiadamiania o tym księcia (princeps), by dowiedzieć się, czy nie ma zastrzeżen. przeciw elektowi.

Zwyczaj przydzielania przez świeckich prebend i beneficjów kościelnych jest niewłaściwy i nie może ulec zasiedzeniu, gdyż prawo rozdawania beneficjów ma charakter duchowy, chyba że istnieje przywilej papieski. Prawo zaś mianowania przez książąt prepozytów kościołów katedralnych, opatów lub innych dygnitarzy niższych od biskupa podobne jest do prawa przysługującego patronom $w$ stosunku do. poszczególnych kościołów. Inną sytuację może uzasadnić jeđynie przywilej papieski.

Zniesiony jest zwyczaj posiadania w Kościele kilku godności lub patronatów bez obowiązku duszpasterstwa, nieprawomocne jest więc posiadanie $w$ tym samym kościele choćby dwóch tylko patronatów, godności, prepozytur lub jedynie godności wraz $z$ patronatem. Nikt nie może mieć równocześnie kilku beneficjów, jeśli jedno wystarcza na jego utrzymanie. W takim przypadku wyłącznie biskup dla słusznej przyczyny może inaczej postanowić.

Zwyczaj nieskładania dziesięciny może być prawomocny, zwłaszcza gdy księża nie proszą o nią lub jej nie potrzebują, ale zwyczaj jej składania jest godziwy (tu odsyłacz do książki Pawła Piaseckiego).

Autor zauważa wreszcie, że zwyczaje zniosly wiele przepisów prawa kanonicznego, np. w dziedzinie postów lub świętowania w określone dni.

$\mathrm{Na}$ końcu zbioru znajduje się 71 aksjomatów dotyczących ustaw (Axiomata, seu sententiae iuris de constitutionibus seu legibus). Zostaly one zaczerpnięte $\mathrm{z}$ ówczesnego prawa kościelnego oraz $\mathrm{z}$ dziel niektórych jego komentatorów, zwłaszcza Henryka de Segusia (card. Hostiensis, $\dagger$ 1271), a także $z$ innych autorów, np. $z$ Arystotelesa.

Wywody autora omawianej pracy opierają się w pierwszej części 
(rozdziały I-V) zasadniczo na Dekretałach papieża Grzegorza IX oraz na ich uzupelnieniach, dokonanych zwłaszcza przez Sobór Trydencki. Zostały także uwzględnione poglądy wielu późniejszych prawników. Sa to $\mathrm{m}$. in. Soto, Tiraqueau, Azor, Menochius, Sanchez, Suárez, Barbosa, a z Polaków Pawel Piasecki (1579-1649), autor wielokrotnie wydawanego dzieła Praxis episcopalis. Zwracaja uwage precyzyjne odsyłacze do dziel przytaczanych autorów, natomiast przy powoływaniu się na Dekretały często stosowano przyjęty dawniej sposób, tj. cytowanie początkowych wyrazów rozdziału i tytułu bez podawania liczby rozdziału lub księgi.

Druga czesść rozprawy, a zwłaszcza rozdziały VI i VII, posiada inny, bardziej samodzielny charakter: podaje wiele propozycji poprawek do prawa cywilnego, przede wszystkim polskiego, $w$ oparciu o prawo kanoniczne. $Z$ przedstawionego poprzednio omówienia tych propozycji wynika, że w większości były one właściwe i bardzo na czasie. Wolno chyba sądzić, że wywarly one pewien wplyw na prawodawstwo cywilne w Polsce.

Conclusiones canonicae Ageisona obejmują wprawdzie tylko część . prawa, reprezentują jednak dość wysoki poziom glównie dzięki uwzględnieniu aspektu referującego (I część) i reformatorskiego (II część) i dlatego zasługują na uwagę.

\section{Gorgonius Ageison SJ (1604-1665), professor in Academia Vilnensî}

Ageison, Danus, unus ex maioris notae professoribus Academiae Vilnensis fuit, in qua philosophiam, theologiam et ius canonicum docuit. Cuius tamen vita et activitas parum nota est. In hoc articulo, praemissis essentialibus vitam eius attinentibus, quae praesertim ex Archivo Romano S. J. deprompta sunt, probatur primum Ageison auctorem esse opusculi Mundus philosophicus (Vilnae 1643), quod pro disputatione publica praeparavit et quod theses continet ex philosophia naturae (physica), deinde praecipuae eius opiniones ibidem contentae referuntur et demum eius conceptiones describuntur in luce sui opusculi Conclusiones canonicae de constitutionibus ecclesiasticis (Vilnae 1652 ), quae pariter pro sollemni disputatione ibidem instituta compositae sunt.

Philosophia in opusculo Mundus philosophicus exposita indolem ecclecticam praesefert. Maximum in eam influxum exercuit Aristoteles, cuius placita paulo immutata sunt a Thoma Aquinate (vg. creatio mundi in tempore). Notabilem quoque influxum exercuit Suárez: materia prima propriam habet existentiam et quodammodo etiam quantitatem, intellectus agens non differt realiter a possibili etc. In explicanda vero natura corporum Ageison atomismum profitetur, continuum ex minimis naturalibus intrinsece indivisibilibus componi asserens.

Conclusiones canonicae daubus constant partibus: prima innititur Decretalibus Gregorii IX, quamquam in ea etiam quidam recentiores canonistae recensiti sunt, in secunda vero parte (capita VI et VII) maior quaedam auctoris autonomia et indoles propria elucet, cum explicare conetur, quomodo lex civilis, praesertim in Polonia, a iure canonico corrigi debeat. Ageison admittit principium, secundum quod licet sequi opinionem probabilem seposita opinione probabiliore. 